\title{
PARASITISM OF BACTERIAL NODULES BY THE RENIFORM NEMATODE
}

The reniform or kidney-shaped nematode, Rotylenchulus reniformis Linford and Oliveira 1940, was originally described from cowpeas, Vigna sinensis Endl. in Hawaii'. In a second publication of the same year 6.5 species of plants were listed as hosts, among them 9 leguminous plants 2 Since then it has been reported as occurring in many other crops, including Phaseolus vulgaris L.. ${ }^{3}$, and Emelista lora (L.) Britton and Rose ${ }^{4.5}$. Although these legumes regularly carry bacterial nodules on their roots no instance of the attachment and feeding on such nodules by this nematode appears to have been recorded. Such an observation is recorded here.

In a recent greenhouse experiment concerning a study of the susceptibility of six plant species to the attacks of an undescribed species of Rolylenchulus, obtained from pigeonpeas, Cajanus indicus Spreng., from the Isabela Substation, many of the bacterial nodules of the pigeonpea roots were obsei ved attacked by females of the reniform nematode. Several of these fully grown females, covered by their gelatinous secretions containing eggs, and with adhering soil particles were seen (fig. 1,A). Five females, each covered by the mentioned gelatinous secretion, and a sixth one without such are shown. As may be seen, the size of the females on these nodules as well as their gelatinous cover is identical with those attached directly to the roots.

In figure 1, B, two females from which the gelatinous cover and adherent soil particles had been removed may be seen enlarged attached to a bacterial

I Jinford, M. B., and Cliveira, J. M., Rotylenchulus reniformis nov. gen., n. sp., a nematode parasite of rools, Pror. Helminth. Sor. Wash. 7 (1) 35-42, 1940.

"Linford, M. B., and Yal), F., Some host plants of the reniform nematode in Hawaii, Proc. Helminth. Soc. Wash. 7 (1) $42-4,1940$.

${ }^{3}$ l'encock, F. C., The reniform nemat ode in the (iold coast, Nematol. 1 (4) 305-10, 1953.

ISteiner, (i., Plant nematodes the grower should know, Soil Sor. of Fla. 4 72-117, 1912.

${ }^{5}$ Siteiner (i.. Some little-known nematodes parasitic on roots, Phytopalh. 37 (6) 441, 1947. 

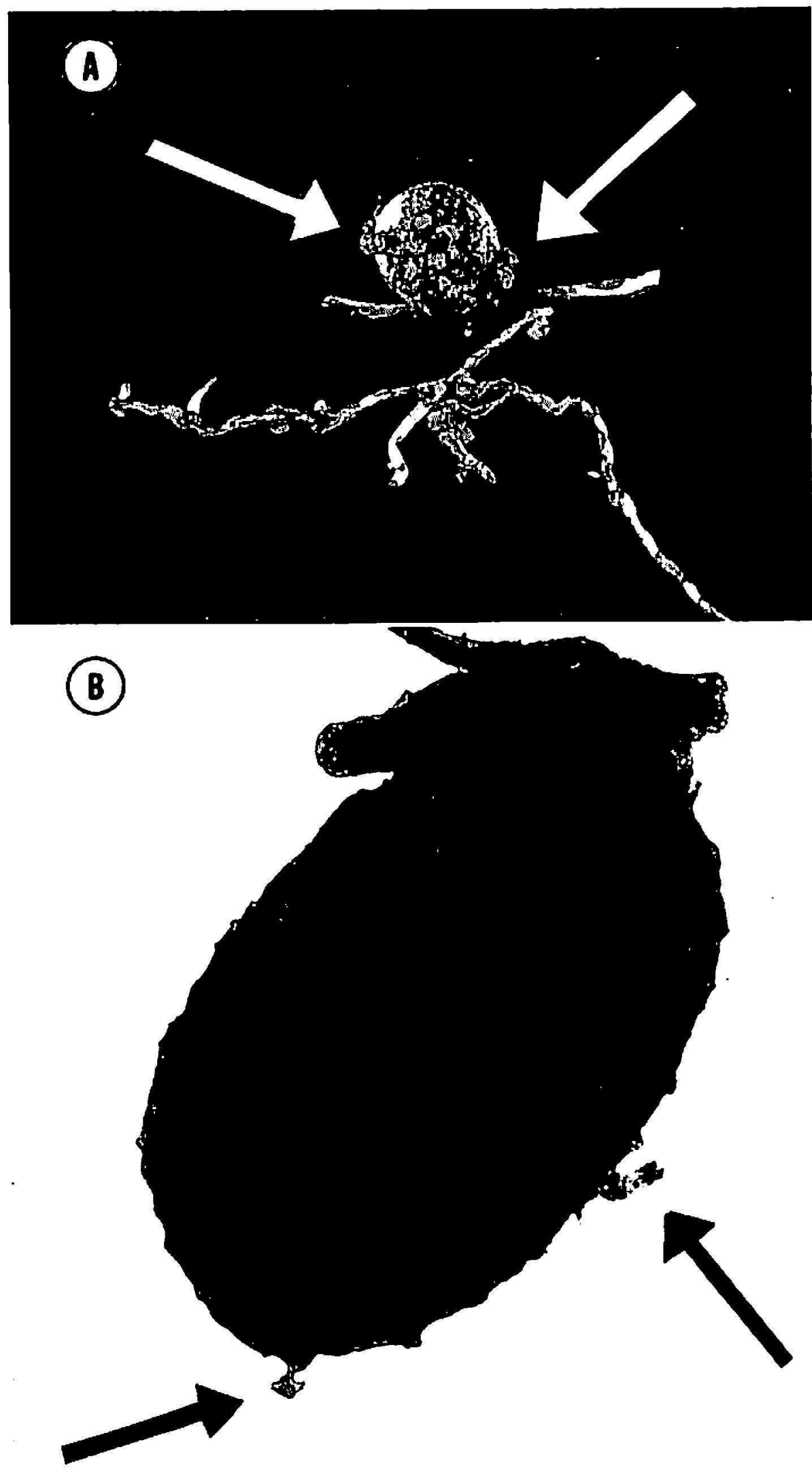

FIG. 1.-The reniform or kidney-shajed nematode, Rolylenchulus n. sp. A, Pieces of Cajanus indicus roots with specimens of Rolylenchulus sp., and bacterial nodules with females attached. Notice 5 females covered with gelatinous secretion with eggs and soil particles, and olserve uncovered female. B, Close-up of a bacterial nodule of the same roots to which females are at tached. The gelatinous secretions have been removed to expose the female nematodes. (Pictures taken at USD)A laboratories in Beltsville, Md., through courtesy of the Nematology Section). 
nodule. One may notice the small size of the nematode compared to that of the nodule.

How the nematodes affect the bacterial nodules and whether they feed on the bacteria or on the cortical tissue around them has not been investigated. But it is evident that they are feeding on the nodules since development is achieved and eggs are produced as by those parasitizing the roots directly.

Alejandro Ayala

Department of Entomology 